\title{
CD39/CD73 and the imbalance of Th17 cells and regulatory $T$ cells in allergic asthma
}

\author{
LIN-LIN WANG ${ }^{1}$, HUA-PING TANG ${ }^{2}$, GUO-CHAO SHI $^{1}$, HUAN-YING WAN $^{1}$, \\ WEI TANG ${ }^{1}$, XIAO-XIA HOU ${ }^{1}$, LI-NA PAN ${ }^{1}$, BAO-YU SHI ${ }^{1}$ and LIAN-QIN TAO ${ }^{1}$ \\ ${ }^{1}$ Department of Pulmonary Medicine, Ruijin Hospital, Shanghai Jiao Tong University School of Medicine, \\ Shanghai 200025; ${ }^{2}$ Department of Pulmonary Medicine, Qingdao Municipal Hospital, \\ Qingdao University School of Medicine, Qingdao, Shandong 266011, P.R. China
}

Received March 10, 2013; Accepted August 21, 2013

DOI: $10.3892 / \mathrm{mmr} .2013 .1692$

\begin{abstract}
In the immune system, $\mathrm{CD} 4^{+} \mathrm{CD} 25^{+} \mathrm{Foxp} 3^{+}$regulatory $\mathrm{T}$ cells (Tregs) maintain self-tolerance and Th17 cells mediate inflammatory responses. CD39 is expressed on the surface of a subset of naturally occurring human Tregs that are important in constraining pathogenic Th17 cells. Additional studies have shown that Tregs differentiate into interleukin-17 $(\mathrm{IL}-17)^{+} \mathrm{Foxp}^{+} \mathrm{T}$ cells. Our previous study indicated an imbalance of Th17 and Tregs in allergic asthma; however, the underlying mechanisms remain poorly understood. Using quantitative PCR (qPCR), CD39 and CD73 mRNA levels in $\mathrm{CD}^{+} \mathrm{T}$ cells were investigated. Flow cytometry was used to analyze the proportion of IL- $17^{+}$Foxp $3^{+} \mathrm{T}$ cells, and CD39 and CD73 expressed by $\mathrm{CD}^{+} \mathrm{T}$ cells and Tregs in the peripheral blood of the subjects. The results of the present study demonstrated an increased frequency of $\mathrm{CD} 4^{+} \mathrm{Foxp} 3^{+} \mathrm{IL}-17^{+} \mathrm{T}$ cells in moderate to severe asthma. A deficiency in CD39 expressed on the surface of $\mathrm{CD} 4^{+} \mathrm{T}$ cells and Tregs was observed in asthma patients. The expression of CD39 and CD73 on the surface of $\mathrm{CD}^{+} \mathrm{T}$ cells and Tregs was negatively correlated with the number of Th17 cells. These results indicated that the plasticity of Tregs transforming to $\mathrm{IL}-17^{+} \mathrm{Foxp} 3^{+} \mathrm{CD} 4^{+} \mathrm{T}$ cells, the reduced frequency of $\mathrm{CD} 9^{+}$Tregs and less effective suppression of IL-17 production by residual CD39+ Tregs leads to an imbalance of Th17 and Tregs in asthma. Therefore, enhanced CD39 activity is hypothesized to prevent the progression of asthma.
\end{abstract}

Correspondence to: Professor Guo-Chao Shi, Department of Pulmonary Medicine, Ruijin Hospital, Shanghai Jiao Tong University School of Medicine, 197 Ruijin Er Road, Shanghai 200025, P.R. China

E-mail: shiguochao@hotmail.com

Key words: allergic asthma, CD39, CD73, Th17 cells, regulatory $\mathrm{T}$ cells

\section{Introduction}

CD $4{ }^{+} \mathrm{CD} 25^{+}{ }^{-}$oxp $3{ }^{+}$regulatory $\mathrm{T}$ cells (Tregs) have a broad immunosuppressive capacity and are central in regulating self-tolerance and homeostasis in the immune system (1). Th17 cells are important contributors to the inflammatory response (2). A number of studies have demonstrated that Th17 cells and Tregs exhibit unique profiles of cytokines and regulatory transcription factors (3-5). The differentiation and development of Th17 cells is dependent on the transcription factor, ROR- $\gamma \mathrm{t}(6,7)$, while Tregs require TGF- $\beta$ and the forkhead transcription factor, Foxp3 (8).

Although a number of $\mathrm{T}$ cell lineages exhibit distinct gene expression and regulation signatures, each subset retains substantial developmental plasticity (4). However, it is suggested that Th17 cells and Tregs exhibited greater developmental plasticity than Th1 and Th2 cells (9). A number of studies have shown that Tregs are able to differentiate into $\mathrm{CD}^{+}{ }^{+}$Foxp3 $3^{+}$interleukin-17 (IL-17) ${ }^{+} \mathrm{T}$ cells in the colitic microenvironment, colon carcinoma, psoriasis, allergic rhinitis and polyposis (10-12). However, the biological mechanisms of $\mathrm{CD} 4^{+}$Foxp $3^{+} \mathrm{IL}-17^{+} \mathrm{T}$ cells remain poorly understood in allergic asthma. The mechanisms of Treg suppression on effector $\mathrm{T}$ cells (Teffs) remain unclear, but include cell-cell contact and the release of the soluble mediators, IL-10 and TGF- $\beta$. Surface molecules linked to Treg suppression, include the CCR4 and CCR8 chemokine receptors, CTLA-4, the CD103 integrin, the CD62L selectin and CD127 (13-17). CD39 is an ectonucleotidase that catalyzes ATP/ADP to form AMP, which is cleared by CD73 to form adenosine and CD39. CD73 expression was observed on the surface of $\mathrm{CD}^{+} \mathrm{T}$ cells, particularly in a subpopulation of Tregs $(18,19)$. Extracellular ATP has multiple proinflammatory effects, including promoting the secretion of IL-17 and the maturation of dendritic cells, and inducing the apoptosis of Tregs (18-20); thus, its removal may result in anti-inflammatory effects. Adenosine, which functions via the $\mathrm{A}_{2 \mathrm{~A}}$ adenosine receptor expressed on the surface of $\mathrm{T}$ cells, is critical in inhibiting the functions of activated Teffs (21). A previous study observed that CD39+ ${ }^{+}$Treg cells from patients with multiple sclerosis (MS) suppressed pathogenic Th17 cells (20). However, the involvement of CD $39^{+}$Tregs in allergic asthma remains unclear. 
Table I. Primer sequences of CD39, CD73, Foxp3, ROR- $\gamma$ t and $\beta$-actin.

\begin{tabular}{ll}
\hline Gene & \multicolumn{1}{c}{ Primer } \\
\hline CD39 & 5'-CTG ATT CCT GGG AGC ACA T-3' $(\mathrm{bp})$ \\
& 5'-GAC ATA GGT GGA GTG GGA GAG-3' \\
CD73 & 5'-TTC TAA ACA GCA GCA TTC CT-3' \\
& 5'-AAC ATT TCA TCC GTG TGT CT-3' \\
Foxp3 & 5'-ATG CGA CCC CCT TTC ACC TAC-3' \\
& 5'-TGG CGG ATG GCG TTC TTC-3' \\
ROR- $\gamma$ t & 5'-GGC TCC CTG GAT GAA TAG AAT G-3' \\
& 5'-AGG CAG AGG CAG AAA ATG TAA AG-3' \\
3-actin & 5'-AAG GTG ACA GCA GTC GGT T-3' \\
& 5'-TGT GTG GAC TTG GGA GAG G-3' \\
\hline
\end{tabular}

In the current study, the unrecognized functions of CD39 expressed by $\mathrm{CD} 4^{+} \mathrm{T}$ cells and Tregs in controlling Th17 cells were investigated. An understanding of these functions may demonstrate the uncontrolled function of pathogenic $\mathrm{T}$ cells in allergic asthma.

\section{Subjects and methods}

Subjects and sample preparation. Patients with allergic asthma from outpatient clinics at the Department of Pulmonary Medicine, Ruijin Hospital (Shanghai, China) were consecutively recruited into the study. Asthma severity was assessed based on the Global Initiative for Asthma (GINA) (22). All participants performed a forced expiratory volume in the first second (FEV1 \% pred) test, asthma control questionnaire (ACQ) and allergen tests. Patients had not been treated with systemic glucocorticoids for one month prior to the study and had never been treated with other immunosuppressive agents or undergone desensitization therapy. Healthy donors, with normal pulmonary function and negative allergy tests, were selected as normal controls. Heparinized peripheral venous blood $(8 \mathrm{ml})$ was collected from each participant. Written informed consent was obtained from all individuals and the study received ethical approval from the Research Ethics Board of Ruijin Hospital, Shanghai Jiao Tong University School of Medicine (Shanghai, China).

Flow cytometry and antibodies. Expression markers on the surface of $\mathrm{T}$ cells were determined by fluorescence-activated cell sorting analysis, following surface staining or intracellular staining with specific anti-human antibodies. Antibodies included CD4/CD25-fluorescein isothiocyanate (FITC)/ allophycocyanin (APC), CD39-PE-cy7, CD73-Percp5.5, Foxp3-PE, IL-17A-FITC and CD4-PE-cy5 (eBiosciences, San Diego, CA, USA).

For the analysis of Th17 cells and CD4 ${ }^{+}$Foxp $3^{+} \mathrm{IL}-17^{+}$ T cells, $1 \mathrm{ml}$ blood was added to $1 \mathrm{ml}$ Dulbecco's modified Eagle's medium (Gibco-BRL, Carlsbad, CA, USA) and the mixture was stimulated with $20 \mathrm{ng} / \mathrm{ml}$ phorbol 12 -myristate-13-acetate and $1 \mu \mathrm{g} / \mathrm{ml}$ ionomycin in the presence of $2 \mathrm{mmol} / \mathrm{ml}$ monensin (eBiosciences). Following culture (4 $\mathrm{h} ; 37^{\circ} \mathrm{C} ; 5 \% \mathrm{CO}_{2}$ ), red cell lysing solution was added to lyse red blood cells and cells were washed once in phosphate-buffered saline. Cells were incubated with CD4-PE-cy5 at $4^{\circ} \mathrm{C}$ for $30 \mathrm{~min}$, fixed and permeabilized with Perm/Fix solution (eBiosciences) according to the manufacturer's instructions, and were stained with Foxp3-PE and IL-17A-FITC. For the analysis of $\mathrm{CD} 39^{+}$and $\mathrm{CD} 73^{+}$Tregs, cells were incubated with CD4/CD25-FITC/APC and CD39-PE-cy7 or CD73-Percp5.5 at $4^{\circ} \mathrm{C}$ for $30 \mathrm{~min}$, fixed and permeabilized with Perm/Fix solution, and stained with Foxp3-PE.

Quantitative PCR ( $P$ PCR). CD $4^{+} \mathrm{T}$ cells were obtained from peripheral blood using a human $\mathrm{CD}^{+} \mathrm{T}$ cell enrichment cocktail (Stem Cell Technologies Inc., Vancouver, BC, Canada) by Ficoll-Hypaque density centrifugation. Total RNA in the $\mathrm{CD}^{+} \mathrm{T}$ cells was isolated with TRIzol reagent (Invitrogen Life Technologies, Carlsbad, CA, USA) and was reverse transcribed into cDNA (Promega Corporation, Madison, WI, USA). Primers were designed by Invitrogen Life Technologies and synthesized by BioTNT (Shanghai, China), according to the manufacturer's instructions. For amplification, the SYBR-Green I qPCR kit was used (BioTNT). Each reaction was run in triplicate on the ABI villa7 real time PCR system (Invitrogen Life Technologies, Carlsbad, CA, USA) and was normalized to housekeeping gene $\beta$-actin transcripts. Specific primers used are listed in Table I.

Statistical analysis. GraphPad Prism 5 software (GraphPad Software, Inc., La Jolla, CA, USA) was used for statistical analysis. Homogeneity of variance in the three groups was tested first. If each group showed homogeneity, analysis was performed using one way analysis of variance followed by Student-Newman-Keuls test and the data are presented as the mean \pm SD. When heteroscedasticity was present in each group, data were analyzed using the Mann-Whitney test and are presented as medians (interquartile range). Pearson's correlation was used to analyze the relevance. $\mathrm{P}<0.05$ was considered to indicate a statistically significant difference.

\section{Results}

General characteristics of subjects. According to the GINA guidelines, allergic asthmatics may be divided into two 
Table II. Characteristics of subjects for analyzing the expression of CD39 and CD73 protein in CD4+ ${ }^{+}$cells and Treg cells.

\begin{tabular}{lccc}
\hline Characteristics & $\begin{array}{c}\text { Normal control } \\
(\mathrm{n}=20)\end{array}$ & $\begin{array}{c}\text { Intermittent to mild asthma } \\
(\mathrm{n}=23)\end{array}$ & $\begin{array}{c}\text { Moderate to severe asthma } \\
(\mathrm{n}=15)\end{array}$ \\
\hline Allergen test & - & + & + \\
Age (years) & $35.45 \pm 11.9$ & $39.52 \pm 12.28$ & $43.60 \pm 15.07$ \\
Gender (male/female) & $6 / 14$ & $11 / 12$ & $4 / 11$ \\
FEV1 (\% pred) & $94.14 \pm 5.77$ & $79.16 \pm 12.60^{\mathrm{a}}$ & $66.51 \pm 7.04^{\mathrm{ab}}$ \\
ACQ & - & $12.11 \pm 1.73$ & $18.42 \pm 1.38^{\mathrm{b}}$ \\
\hline
\end{tabular}

${ }^{\mathrm{a}} \mathrm{P}<0.01$, vs. normal control and ${ }^{\mathrm{b}} \mathrm{P}<0.01$, vs. mild asthma. FEV1, forced expiratory volume in $1 \mathrm{sec}$; ACQ, asthma control questionnaire.

Table III. Characteristics of subjects for analyzing the expression of CD39, CD73, Foxp3 and ROR- $\gamma \mathrm{t}$ mRNA in CD4 ${ }^{+} \mathrm{T}$ cells.

\begin{tabular}{lccc}
\hline Characteristics & $\begin{array}{c}\text { Normal control } \\
(\mathrm{n}=23)\end{array}$ & $\begin{array}{c}\text { Intermittent to mild asthma } \\
(\mathrm{n}=17)\end{array}$ & $\begin{array}{c}\text { Moderate to severe asthma } \\
(\mathrm{n}=12)\end{array}$ \\
\hline Allergen test & - & + & + \\
Age (years) & $37.26 \pm 11.88$ & $40.24 \pm 11.92$ & $44.33 \pm 14.29$ \\
Gender (male/female) & $10 / 13$ & $7 / 10$ & $3 / 9$ \\
FEV1 (\%pred) & $94.03 \pm 5.39$ & $81.24 \pm 11.35^{\mathrm{a}}$ & $64.34 \pm 6.03^{\mathrm{ab}}$ \\
ACQ & - & $11.52 \pm 2.29$ & $18.07 \pm 1.44^{\mathrm{b}}$ \\
\hline
\end{tabular}

${ }^{\mathrm{a}} \mathrm{P}<0.01$ vs. normal control and ${ }^{\mathrm{b}} \mathrm{P}<0.01$, vs. mild asthma. FEV1, forced expiratory volume in $1 \mathrm{sec}$; ACQ, asthma control questionnaire.

subgroups, intermittent to mild and moderate to severe. No significant differences were identified in terms of age and gender between the patients and normal control groups. FEV1 (\%pred) in patients with moderate to severe asthma was significantly lower than those with intermittent to mild asthma, but the scores for ACQ were of the opposite trend (Tables II and III; note that the number of patients differs between Tables II and III as the patients were recalled for the analysis in table III and not all were available).

Tregs differentiate into $\mathrm{CD} 4^{+} \mathrm{Foxp}^{+} I L-17^{+} \mathrm{T}$ cells in the microenvironment of allergic asthma. The relative frequency of $\mathrm{CD} 4^{+} \mathrm{Foxp} 3^{+} \mathrm{IL}-17^{+} \mathrm{T}$ cells over total Tregs was $4.69 \%$ (2.90-8.01) in healthy controls. However, the frequency in patients with intermittent to mild asthma and moderate to severe asthma was $6.10(4.63-8.70)$ and $16.80 \%(9.13-32.65)$, respectively. $\mathrm{CD} 4{ }^{+} \mathrm{Foxp} 33^{+} \mathrm{IL}-17^{+} \mathrm{T}$ cells were detected in the peripheral blood of patients with allergic asthma. Higher levels were observed in patients with moderate to severe asthma compared with those with intermittent to mild asthma $(\mathrm{P}<0.01)$ and healthy controls $(\mathrm{P}<0.01)$; however, no significant difference was identified between intermittent to mild asthma and healthy controls (Fig. 1).

Decreased CD39 and CD73 on the surface of $C D 4^{+} T$ cells in allergic asthma contributes to the imbalance of Th17 Tregs. Results demonstrated that the proportions of Th17 cells (23) and CD $4{ }^{+}$Foxp $3^{+} \mathrm{IL}-17^{+} \mathrm{T}$ cells were increased in asthma patients Therefore, increased Th17 cells and $\mathrm{CD} 4^{+} \mathrm{Foxp} 3^{+} \mathrm{IL}-17^{+} \mathrm{T}$ cells were hypothesized to be correlated with decreased $\mathrm{CD} 4^{+} \mathrm{CD} 39^{+}$
T cells and $\mathrm{CD}^{+}{ }^{+} \mathrm{CD} 73^{+} \mathrm{T}$ cells. Thus, the mRNA and protein levels of CD39 and CD73 in CD4 ${ }^{+} \mathrm{T}$ cells were investigated. The correlation between the levels CD39 and CD73 expressed by $\mathrm{CD} 4^{+} \mathrm{T}$ cells and Th17 cells, CD $4^{+} \mathrm{Foxp} 3^{+} \mathrm{IL}-17^{+} \mathrm{T}$ cells and disease severity were analyzed.

CD39 mRNA in CD4 ${ }^{+} \mathrm{T}$ cells was significantly lower in patients with moderate to severe asthma compared with those with intermittent to mild asthma [0.15 $(0.10-0.19) \times 10^{-3}$ vs. $\left.0.27(0.19-0.39) \times 10^{-3} ; \mathrm{P}<0.01\right]$ and healthy controls [0.15 (0.10-0.19) $\times 10^{-3}$ vs. $0.55(0.34-0.70) \times 10^{-3}$; $\mathrm{P}<0.001]$ and there was also a significant difference between intermittent to mild asthma and healthy controls $(\mathrm{P}<0.01$; Fig. 2); however, CD73 mRNA in $\mathrm{CD}^{+} \mathrm{T}$ cells was significantly lower in patients with intermittent to mild asthma compared with healthy controls (Fig. 3). The relative frequency of $\mathrm{CD} 4{ }^{+} \mathrm{CD} 39^{+} \mathrm{T}$ cells in the peripheral blood was significantly higher in healthy controls compared with patients with intermittent to mild asthma $(10.77 \pm 3.94$ vs. $3.84 \pm 2.58 \% ; \mathrm{P}<0.001)$ and with moderate to severe asthma $(10.77 \pm 3.94$ vs. $4.43 \pm 4.13 \%$; $\mathrm{P}<0.001)$; however, there was no significant difference identified between the two subgroups of asthma (Fig. 4). No significant differences in the levels of $\mathrm{CD} 4{ }^{+} \mathrm{CD}_{73}{ }^{+} \mathrm{T}$ cell levels were identified among these three groups (Fig. 4).

Correlation analysis indicated that CD39 mRNA expression was positively correlated with Foxp3 mRNA expression $(\mathrm{r}=0.484 ; \mathrm{P}<0.001)$ and negatively correlated with ROR- $\gamma \mathrm{t}$ $(\mathrm{r}=-0.272, \mathrm{P}=0.051)$. In addition, the frequency of Th17 cells was negatively correlated with the relative frequencies of $\mathrm{CD} 4{ }^{+} \mathrm{CD} 39^{+} \mathrm{T}$ cells and $\mathrm{CD} 4{ }^{+} \mathrm{CD} 73^{+} \mathrm{T}$ cells $(\mathrm{r}=-0.348, \mathrm{P}<0.05$ 


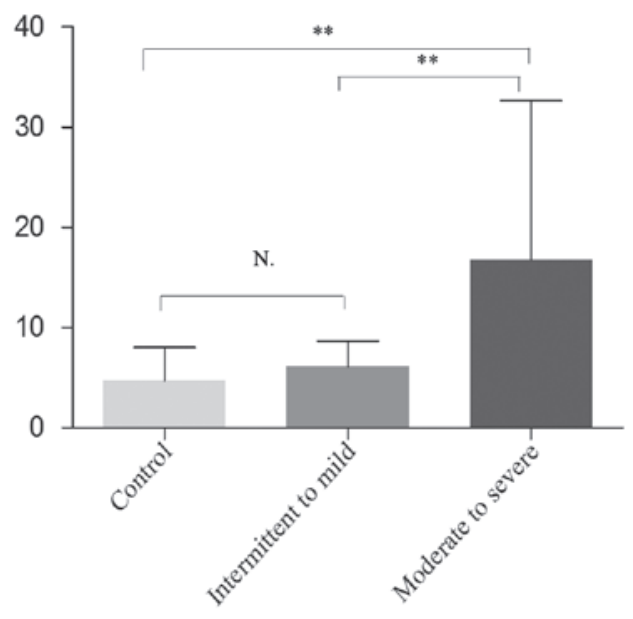

Figure 1. Frequency of $\mathrm{CD} 4^{+} \mathrm{Foxp} 3^{+} \mathrm{IL}-17^{+} \mathrm{T}$ cells relative to Treg cells as detemined by flow cytometry. ${ }^{* *} \mathrm{P}<0.01$, vs. control or intermittent to mild groups. Treg, $\mathrm{CD}_{4}{ }^{+} \mathrm{CD} 25^{+} \mathrm{Foxp}^{+}$regulatory T cell; IL-17, interleukin-17.

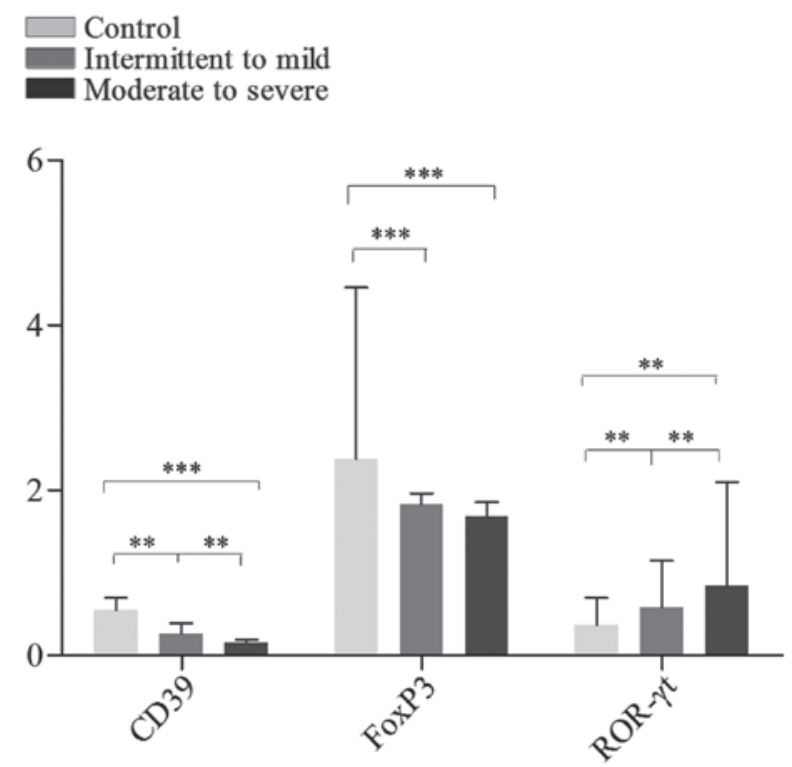

Figure 2. Expression of CD39, Foxp3 and ROR- $\gamma \mathrm{t}$ mRNA in CD4 ${ }^{+} \mathrm{T}$ cells as determined by qPCR in each group. ${ }^{* *} \mathrm{P}<0.01$, vs. control or intermittent to mild groups; ${ }^{* * * *} \mathrm{P}<0.001$, vs. control. qPCR, quantitative PCR.

and $\mathrm{r}=-0.428$, respectively; $\mathrm{P}<0.05$; Table IV). However, the frequency of $\mathrm{CD} 4^{+} \mathrm{Foxp} 3^{+} \mathrm{IL}-17^{+} \mathrm{T}$ cells was not observed to be correlated with the relative frequencies of $\mathrm{CD} 4^{+} \mathrm{CD} 39^{+} \mathrm{T}$ cells and $\mathrm{CD} 4^{+} \mathrm{CD} 73^{+} \mathrm{T}$ cells (Table IV).

$\mathrm{CD}_{39^{+}}$and $\mathrm{CD} 3^{+}$Treg cells are significantly decreased in the peripheral blood of patients with allergic asthma. Impaired function of Tregs was responsible for airway inflammation in allergic asthma. Preliminary studies indicated that the functional deficiency of Tregs results from a decrease in the number and capacity of cells secreting IL-10 and TGF- $\beta$, as well as a number of other factors. Tregs have been observed to coexpress CD39 and CD73 enzymes, which catalyze ATP and ADP into adenosine where adenosine binds to the $\mathrm{A}_{2 \mathrm{~A}}$ receptor expressed by Teffs to suppress inflammatory responses (18). CD39+ ${ }^{+}$Treg cells have been reported to be important in

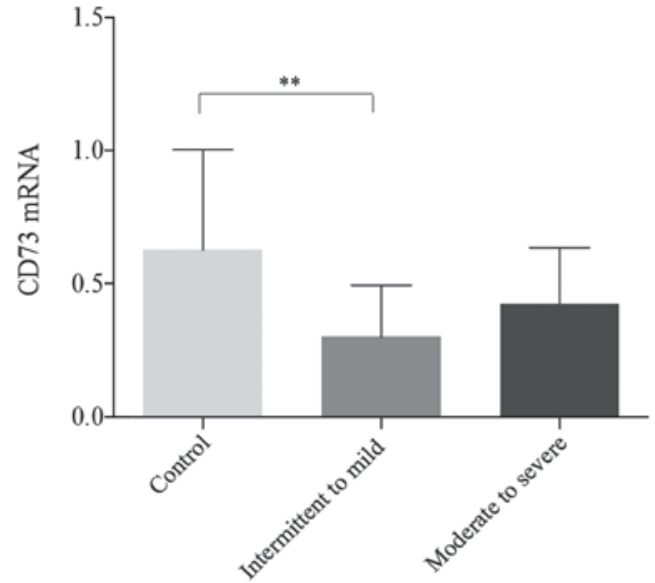

Figure 3. Expression of CD73 mRNA in CD4 ${ }^{+} \mathrm{T}$ cells as determined by qPCR in each group. ${ }^{* *} \mathrm{P}<0.01$, vs. control. qPCR, quantitative PCR.

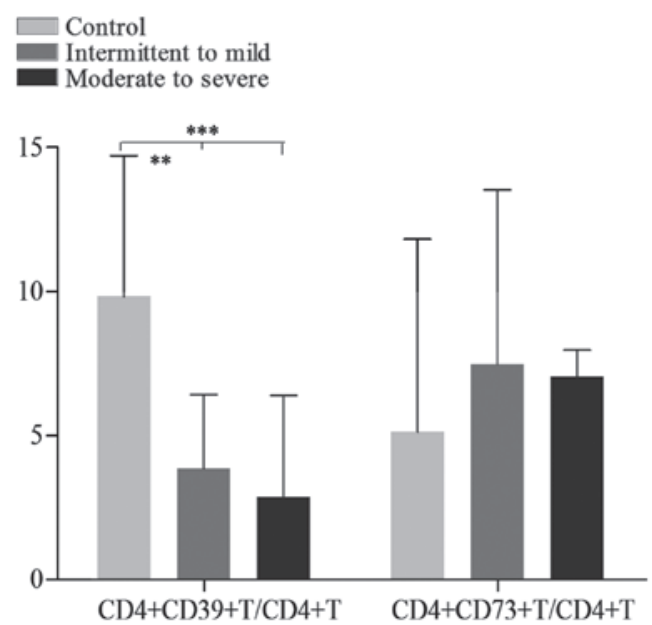

Figure 4. Frequencies of $\mathrm{CD} 4^{+} \mathrm{CD} 39^{+} \mathrm{T}$ cells and $\mathrm{CD} 4^{+} \mathrm{CD} 73^{+} \mathrm{T}$ cells relative to $\mathrm{CD} 4{ }^{+} \mathrm{T}$ cells as determined by flow cytometry. ${ }^{* * *} \mathrm{P}<0.01 ;{ }^{* * * *} \mathrm{P}<0.001$, vs. control or intermittent to mild group.

constraining pathogenic Th17 cells in MS (21). Further studies are required to determine the mechanisms of the imbalance of Th17 and Tregs in allergic asthma.

The proportions of $\mathrm{CD}_{3} 9^{+}$and $\mathrm{CD} 3^{+}$Treg cells over total Tregs in the peripheral blood were significantly higher in healthy controls compared with patients with intermittent to mild asthma [85.18 (79.04-88.12) vs. 29.41 (19.80-52.98)\%; $\mathrm{P}<0.001$ and $34.78(26.30-54.23)$ vs. 6.46 (4.98-11.71)\%; $\mathrm{P}<0.001$, respectively] and with moderate to severe asthma [85.18 (79.04-88.12) vs. 36.02 (27.47-66.91)\%, $\mathrm{P}<0.001$ and 34.78 (26.30-54.23) vs. 10.50 (7.69-13.98)\%; $\mathrm{P}<0.001$, respectively]. No significant differences were identified between the two subgroups of asthma $(\mathrm{P}=0.226$ and $\mathrm{P}=0.051$, respectively; Figs. 5 and 6). The relative frequency of Th17 cells demonstrated a similar trend in the opposite direction. The frequency of Th17 cells was observed to be negatively correlated with the relative frequencies of $\mathrm{CD}^{+}{ }^{+}$and $\mathrm{CD}^{+} 3^{+}$Treg cells $(\mathrm{r}=-0.377$, $\mathrm{P}<0.05$ and $\mathrm{r}=-0.428, \mathrm{P}<0.05$, respectively; Table IV). The relative frequency of $\mathrm{CD} 4^{+} \mathrm{Foxp} 3^{+} \mathrm{IL}-17^{+} \mathrm{T}$ cells was not shown to be correlated with the relative frequencies of $\mathrm{CD} 39^{+}$and CD73+ Tregs (Table IV). 
Table IV. Results of correlation analysis.

\begin{tabular}{|c|c|c|c|c|c|c|c|c|}
\hline \multirow[b]{2}{*}{ Cell type } & \multicolumn{2}{|c|}{$\mathrm{CD}^{+}{ }^{+} \mathrm{CD} 39^{+} \mathrm{T}$ cells } & \multicolumn{2}{|c|}{$\mathrm{CD} 4^{+} \mathrm{CD} 73^{+} \mathrm{T}$ cells } & \multicolumn{2}{|c|}{$\mathrm{CD} 9^{+}$Tregs } & \multicolumn{2}{|c|}{$\mathrm{CD}^{2+} 3^{+}$Tregs } \\
\hline & r-value & P-value & r-value & P-value & r-value & P-value & $\mathrm{r}$-value & P-value \\
\hline $\mathrm{CD}^{+}{ }^{+} \mathrm{Foxp} 3^{+} \mathrm{IL}-17^{+} \mathrm{T}$ cells & $\mathrm{r}=-0.20$ & $\mathrm{P}=0.915$ & $\mathrm{r}=-0.031$ & $\mathrm{P}=0.872$ & $\mathrm{r}=-0.038$ & $\mathrm{P}=0.841$ & $\mathrm{r}=-0.052$ & $\mathrm{P}=0.784$ \\
\hline Th17 cells & $r=-0.348$ & $\mathrm{P}<0.05$ & $\mathrm{r}=-0.428$ & $\mathrm{P}<0.05$ & $\mathrm{r}=-0.377$ & $\mathrm{P}<0.05$ & $r=-0.428$ & $\mathrm{P}<0.05$ \\
\hline
\end{tabular}

Treg, regulatory T cell. IL-17, interleukin 17.

A

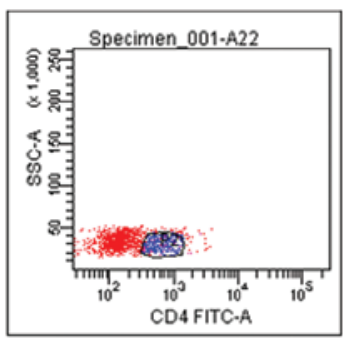

B

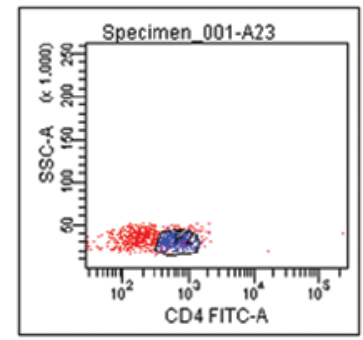

C

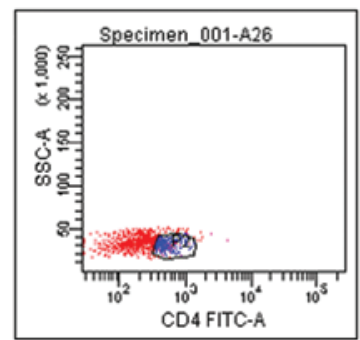

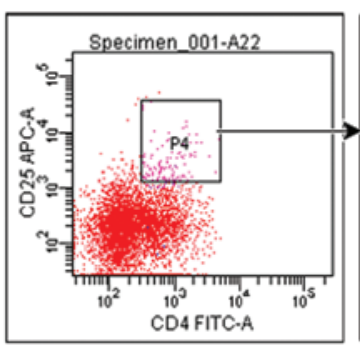
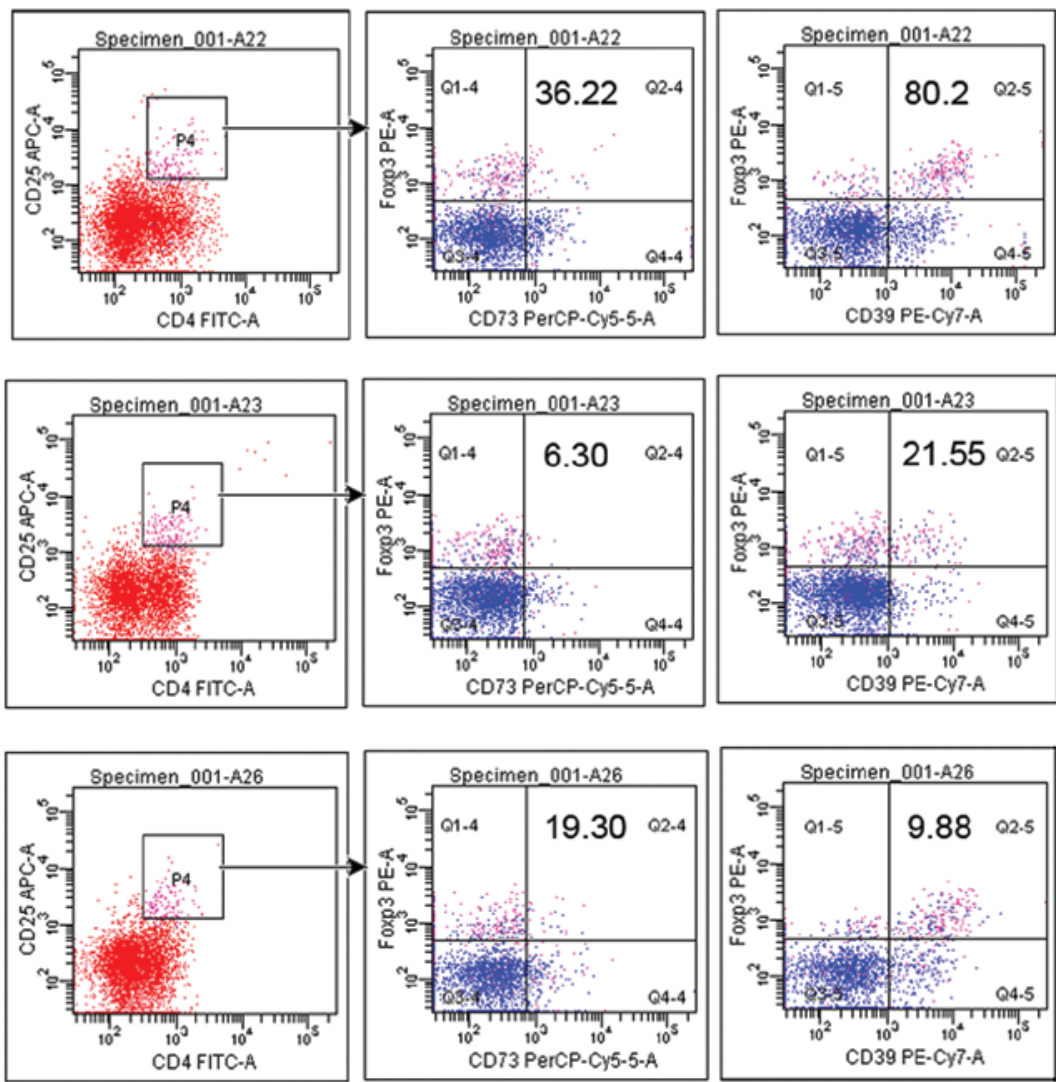

Figure 5. Frequencies of $\mathrm{CD} 39^{+}$Tregs and $\mathrm{CD} 73^{+}$Tregs relative to Treg cells as determined by flow cytometry in each group. (A) Control, (B) intermittent to mild and $(\mathrm{C})$ moderate to severe groups. Treg, $\mathrm{CD} 4^{+} \mathrm{CD} 25^{+} \mathrm{Foxp} 3^{+}$regulatory $\mathrm{T}$ cell; FITC, fluorescein isothiocyanate.

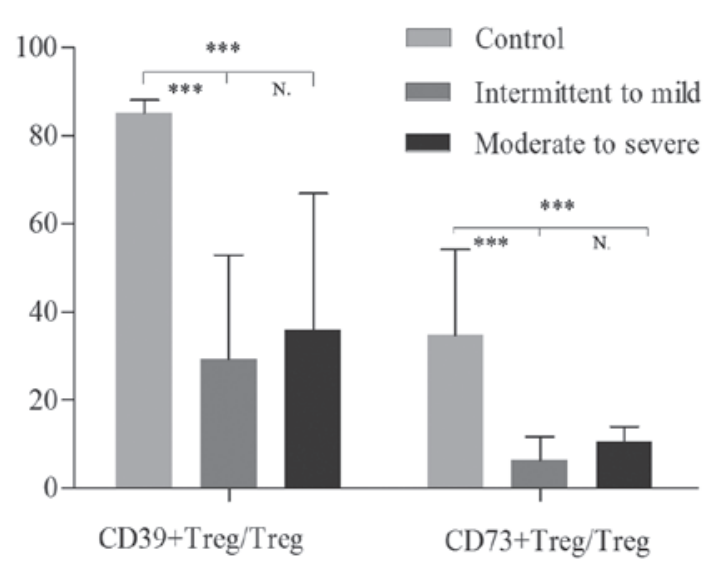

Figure 6. Frequencies of CD39+ Tregs and CD73 ${ }^{+}$Tregs relative to Treg cells as determined by flow cytometry in each group. ${ }^{* * *} \mathrm{P}<0.001$, vs. control or intermittent to mild group. Treg, $\mathrm{CD} 4{ }^{+} \mathrm{CD} 25^{+} \mathrm{Foxp} 3^{+}$regulatory $\mathrm{T}$ cell.

\section{Discussion}

Our previous study demonstrated an increased proportion of Th17 cells and a decreased frequency of Tregs in asthma (23). Correlation analysis indicated that the frequency of peripheral blood Th17 cells was negatively correlated with the percentage of Tregs (23). Thus, the immunosuppressive capacity of Tregs was decreased in the inhibition of inflammatory responses mediated by Th17 cells and there was an imbalance of Th17 cells and Tregs in asthma. However, the underlying mechanisms remain unclear.

It has been shown that Tregs may be converted to Th17 cells $(10,12)$. In the current study, Tregs in patients with asthma were observed to exhibit the capacity to produce IL-17 (CD $4^{+} \mathrm{Foxp}^{+} \mathrm{IL}-17^{+} \mathrm{T}$ cells). $\mathrm{CD} 4^{+} \mathrm{Foxp}^{+} \mathrm{IL}-17^{+} \mathrm{T}$ cells were hypothesized to represent Tregs in the middle stages of transformation into Th17 cells. Furthermore, 
CD $4{ }^{+}$Foxp $3{ }^{+} \mathrm{IL}-17^{+} \mathrm{T}$ cell levels were associated with disease severity. Thus, the imbalance of Th17 cells and Tregs in asthma was hypothesized to be due to the increased capacity of Tregs to transform into Th17 cells. A balance of Foxp3 and ROR- $\gamma$ t has been reported in Tregs, and Foxp3 is known to inhibit the expression of ROR- $\gamma$ t (4). In addition, CD39 promotes the expression of Foxp3, which amplifies and stabilizes the expression of CD39 (24). In the present study, CD39 mRNA was observed to be negatively correlated with ROR- $\gamma$ t mRNA and positively correlated with Foxp3 mRNA in $\mathrm{CD}^{+} \mathrm{T}$ cells. This observation indicates that decreased Foxp3 and CD39 and increased ROR- $\gamma$ t in asthma may be a mechanism of plasticity of Tregs transforming to Th17 cells in asthma.

The correlation between the imbalance of Th17 and Tregs in asthma and the expression of CD39 and CD73 by CD4 ${ }^{+}$ $\mathrm{T}$ cells, particularly Tregs, was then investigated. To the best of our knowledge, this study demonstrated for the first time that a subset of human Tregs expressed CD39 and CD73 in asthma and the relative frequencies of $\mathrm{CD} 4{ }^{+} \mathrm{CD} 39^{+} \mathrm{T}$ cells, CD39+ ${ }^{+}$Tregs and CD $73^{+}$Tregs in the peripheral blood were significantly lower in patients with intermittent to mild asthma compared with healthy controls. These results suggested that CD39 and CD73 may be involved in the occurrence and progression of allergic asthma. CD39 and CD73 expression by Tregs was not identified to be significantly different between asthma subgroups, but there was an increasing trend in the expression observed in patients with moderate to severe asthma. Tregs from individuals with asthma were hypothesized to constitute a deficiency in the mechanism of immunosuppression by increasing CD39 and CD73 expression, although Tregs do not inhibit the progression of asthma.

A number of studies have indicated that human Foxp $3^{+}$Tregs, while capable of suppressing proliferation and IFN- $\gamma$ production, do not suppress the IL-17 production of Teffs $(25,26)$. Mechanisms of suppression of Foxp3 ${ }^{+}$Tregs include cell-cell contact, the release of soluble mediators (IL-10 and TGF- $\beta$ ) and the consumption of IL-2. In the present study, another mechanism, the negative correlation between the decreased relative frequency of CD39+ Tregs and increased Th17 cells, was introduced. Thus, the results indicated that CD39+ ${ }^{+}$Tregs may inhibit the production of IL-17, which is not consistent with certain studies, which have indicated that total Foxp $3^{+}$Tregs do not suppress IL-17 production by $\mathrm{T}$ cells.

The relative frequencies of $\mathrm{CD}_{3} 9^{+}$and $\mathrm{CD}^{+} 3^{+}$Tregs were shown to be reduced in intermittent to mild asthma and there was an increasing trend in moderate to severe asthma. However, the increased relative frequency of CD39+ and $\mathrm{CD}_{73}{ }^{+}$Tregs did not inhibit the progression of asthma. These observations indicated that $\mathrm{CD} 39^{+}$and $\mathrm{CD} 73^{+}$Treg populations in moderate to severe asthma are less effective at suppressing Th17 responses than the same cells from healthy controls. The current study indicated that the upregulation of Th17 cells in asthma may be due to a decrease in the relative frequency and impaired function of $\mathrm{CD} 39^{+}$and $\mathrm{CD}^{+} 3^{+}$Tregs in asthma.

In the present study, the relative frequencies of CD $4{ }^{+}$Foxp $3^{+} \mathrm{IL}_{-1} 17^{+} \mathrm{T}$ cells, Th17 cells and CD39 and CD73 expression by $\mathrm{CD}^{+} \mathrm{T}$ cells and Tregs was determined and their correlation was analyzed. Future studies are likely to investigate the suppressive function of CD39+ Tregs and their biological characteristics in asthma.

In conclusion, the plasticity of Tregs transforming to IL- $17^{+}$Foxp 3 CD $4{ }^{+} \mathrm{T}$ cells, the reduced frequency CD39+ ${ }^{+}$Tregs and the efficacy of suppression of IL-17 production by residual CD39+ ${ }^{+}$Tregs, may lead to the imbalance of Th17 and Tregs in allergic asthma. The observations indicate that enhancing CD39 activity may be beneficial in preventing the progression of asthma.

\section{References}

1. Shevach EM: $\mathrm{CD} 4{ }^{+} \mathrm{CD} 25^{+}$suppressor T cells: more questions than answers. Nat Rev Immunol 2: 389-400, 2002.

2. Tesmer LA, Lundy SK, Sarkar S and Fox DA: Th17 cells in human disease. Immunol Rev 223: 87-113, 2008.

3. Weaver CT, Harrington LE, Mangan PR, Gavrieli M and Murphy KM: Th17: an effector CD4 T cell lineage with regulatory T cell ties. Immunity 24: 677-688, 2006.

4. Zhou L, Chong MM and Littman DR: Plasticity of $\mathrm{CD}^{+} \mathrm{T}$ cell lineage differentiation. Immunity 30: 646-655, 2009.

5. Dong C: TH17 cells in development: an updated view of their molecular identity and genetic programming. Nat Rev Immunol 8: 337-348, 2008.

6. Chen Q, Yang W, Gupta S, Biswas P, Smith P, Bhagat G and Pernis AB: IRF-4-binding protein inhibits interleukin-17 and interleukin-21 production by controlling the activity of IRF-4 transcription factor. Immunity 29: 899-911, 2008.

7. Ivanov II, McKenzie BS, Zhou L, Tadokoro CE, Lepelley A, Lafaille JJ, Cua DJ and Littman DR: The orphan nuclear receptor RORgammat directs the differentiation program of proinflammatory IL-17 ${ }^{+} \mathrm{T}$ helper cells. Cell 126: 1121-1133, 2006.

8. Josefowicz SZ and Rudensky A: Control of regulatory $\mathrm{T}$ cell lineage commitment and maintenance. Immunity 30: 616-625, 2009.

9. Lee YK, Mukasa R, Hatton RD and Weaver CT: Developmental plasticity of Th17 and Treg cells. Curr Opin Immunol 21: 274-280, 2009.

10. Kryczek I, Wu K, Zhao E, Wei S, Vatan L, Szeliga W, Huang E, Greenson J, Chang A, Roliński J, et al: $\mathrm{IL}-17^{+}$regulatory T cells in the microenvironments of chronic inflammation and cancer. J Immunol 186: 4388-4395, 2011.

11. Bovenschen HJ, van de Kerkhof PC, van Erp PE, Woestenenk R, Joosten I and Koenen HJ: Foxp3 $3^{+}$regulatory T cells of psoriasis patients easily differentiate into IL-17A-producing cells and are found in lesional skin. J Invest Dermatol 131: 1853-1860, 2011.

12. Liu T, Song CH, Liu AM, Xie C, Zhao F, Chen X, Cheng L and Yang PC: Forkhead box $\mathrm{P}^{+} \mathrm{T}$ cells express interleukin-17 in nasal mucosa of patients with both allergic rhinitis and polyposis. Clin Exp Immunol 163: 59-64, 2011.

13. Iellem A, Mariani M, Lang R, Recalde H, Panina-Bordignon $P$, Sinigaglia F and D'Ambrosio D: Unique chemotactic response profile and specific expression of chemokine receptors CCR4 and CCR8 by CD4(+)CD25(+) regulatory T cells. J Exp Med 194: 847-853, 2001.

14. Paust S, Lu L, McCarty N and Cantor H: Engagement of B7 on effector $\mathrm{T}$ cells by regulatory $\mathrm{T}$ cells prevents autoimmune disease. Proc Natl Acad Sci USA 101: 10398-10403, 2004.

15. Lehmann J, Huehn J, de la Rosa M, Maszyna F, Kretschmer U, Krenn V, Brunner M, Scheffold A and Hamann A: Expression of the integrin alpha Ebeta 7 identifies unique subsets of $\mathrm{CD}^{2} 5^{+}$as well as CD25- regulatory T cells. Proc Natl Acad Sci USA 99: 13031-13036, 2002.

16. Salomon B, Lenschow DJ, Rhee L, Ashourian N, Singh B, Sharpe A and Bluestone JA: B7/CD28 costimulation is essential for the homeostasis of the $\mathrm{CD} 4{ }^{+} \mathrm{CD} 25^{+}$immunoregulatory $\mathrm{T}$ cells that control autoimmune diabetes. Immunity 12 : 431-440, 2000

17. Liu W, Putnam AL, Xu-Yu Z, Szot GL, Lee MR, Zhu S, Gottlieb PA, Kapranov P, Gingeras TR, Fazekas de St Groth B, et al: CD127 expression inversely correlates with FoxP3 and suppressive function of human $\mathrm{CD}^{+}$Treg cells. J Exp Med 203: $1701-1711,2006$. 
18. Deaglio S, Dwyer KM, Gao W, Friedman D, Usheva A, Erat A Chen JF, Enjyoji K, Linden J, Oukka M, et al: Adenosine generation catalyzed by CD39 and CD73 expressed on regulatory $\mathrm{T}$ cells mediates immune suppression. J Exp Med 204: 1257-1265, 2007.

19. Borsellino G, Kleinewietfeld M, Di Mitri D, Sternjak A, Diamantini A, Giometto R, Höpner S, Centonze D, Bernardi G, Dell'Acqua ML, et al: Expression of ectonucleotidase CD39 by Foxp3 $3^{+}$Treg cells: hydrolysis of extracellular ATP and immune suppression. Blood 110: 1225-1232, 2007.

20. Fletcher JM, Lonergan R, Costelloe L, Kinsella K, Moran B, $\mathrm{O}^{\prime}$ Farrelly C, Tubridy $\mathrm{N}$ and Mills KH: CD $39^{+} \mathrm{Foxp}^{+}{ }^{+}$regulatory T cells suppress pathogenic Th17 cells and are impaired in multiple sclerosis. J Immunol 183: 7602-7610, 2009.

21. Huang S, Apasov S, Koshiba M and Sitkovsky M: Role of A2a extracellular adenosine receptor-mediated signaling in adenosine mediated inhibition of T-cell activation and expansion. Blood 90: 1600-1610, 1997.

22. Boulet LP, FitzGerald JM, Levy ML, Cruz AA, Pedersen S, Haahtela T and Bateman ED: A guide to the translation of the Global Initiative for Asthma (GINA) strategy into improved care. Eur Respir J 39: 1220-1229, 2012.
23. Shi YH, Shi GC, Wan HY, Jiang LH, Ai XY, Zhu HX, Tang W, Ma JY, Jin XY and Zhang BY: Co-existence of Th1/Th2 and Th17/Treg imbalances in patients with allergic asthma and its significance. Chin Med J (Engl) 124: 1951-1956, 2011.

24. Gavin MA, Rasmussen JP, Fontenot JD, Vasta V, Manganiello VC, Beavo JA and Rudensky AY: Foxp3-dependent programme of regulatory $\mathrm{T}$ cell differentiation. Nature 445: 771-775, 2007

25. Flores-Borja F, Jury EC, Mauri C and Ehrenstein MR: Defects in CTLA-4 are associated with abnormal regulatory T cell function in rheumatoid arthritis. Proc Natl Acad Sci USA 105: 19396-19401, 2008.

26. Annunziato F, Cosmi L, Santarlasci V, Maggi L, Liotta F, Mazzinghi B, Parente E, Filì L, Ferri S, Frosali F, et al: Phenotypic and functional features of human Th17 cells. J Exp Med 204: 1849-1861, 2007. 